\title{
Tekanan Waktu Memoderasi Pengaruh Independensi Auditor dan Komitmen Organisasi pada Kinerja Auditor KAP di Provinsi Bali
}

\author{
Made Cintia Arta Pratiwi ${ }^{1}$ \\ Anak Agung Ngurah Bagus Dwirandra ${ }^{2}$ \\ ${ }^{1}$ Fakultas Ekonomi dan Bisnis Universitas Udayana (Unud), Bali, Indonesia \\ email: pratiwi.cintia@yahoo.com/ Telp: +62 81916140022 \\ ${ }^{2}$ Fakultas Ekonomi dan Bisnis Universitas Udayana (Unud), Bali, Indonesia
}

\begin{abstract}
ABSTRAK
Penelitian ini bertujuan untuk menguji kemampuan tekanan waktu memoderasi pengaruh independensi auditor dan komitmen organisasi terhadap kinerja auditor pada Kantor Akuntan Publik di Provinsi Bali yang terdaftar di Institut Akuntan Publik Indonesia tahun 2017. Sampel penelitian ini adalah 76 auditor dengan memakai teknik sampling jenuh sebagai metode penentuan sampel. Metode pengumpulan data yaitu kuesioner. Moderated Regression Analysis (MRA) digunakan sebagai teknik analisis data dalam penelitian ini. Hasil pengujian ini menunjukkan bahwa independensi auditor berpengaruh negatif pada kinerja auditor, komitmen organisasi dan tekanan waktu berpengaruh positif terhadap kinerja auditor serta tekanan waktu tidak mampu memoderasi pengaruh independensi auditor terhadap kinerja auditor dan tekanan waktu tidak mampu memoderasi pengaruh komitmen organisasi terhadap kinerja auditor

Kata kunci: Independensi auditor, komitmen organisasi, tekanan waktu, kinerja auditor
\end{abstract}

\begin{abstract}
This study aims to test the ability of time pressure to moderate the influence of auditor independence and organizational commitment to the performance of auditors at Public Accounting Firm in Bali Province registered with Indonesian Institute of Certified Public in 2017. The sample of this research is 76 auditor by using saturated sampling technique as sample determination method. Data collection method is questionnaire. Moderated Regression Analysis (MRA) is used as a data analysis technique in this study. The results of this test indicate that auditor independence has negative effect on auditor performance, organizational commitment and time pressure have positive effect on auditor performance and time pressure unable to moderate influence of auditor independence to auditor performance and time pressure unable to moderate influence of organizational commitment to auditor performance
\end{abstract}

Keywords: auditor independence, organizational commitment, time pressure, auditor performance

\section{PENDAHULUAN}

Akuntan pada profesi bidang bisnis dengan profesi lainnya memiliki peranan penting di dalam perusahaan. Akuntan dalam melaksanakan tugasnya mempunyai 2 kewajiban dengan merahasiakan segala bukti yang didapat ketika menjalankan pekerjaan serta mempertahankan pekerjaan profesionalnya (Arifah, 2012). 
Made Cintia Arta Pratiwi dan Anak Agung Ngurah Bagus Dwirandra. Tekanan ...

Berkembangnya profesi akuntan publik menunjukkan adanya perkembangan suatu perusahaan dan badan hukum perusahaan. Perusahaan yang semakin berkembang tidak hanya memerlukan modal dari pemiliknya tetapi memerlukan modal juga dari kreditur.

Berkembangnya perusahaan berbadan hukum maka mulai berkembang dan diperlukannya jasa akuntan publik. Auditor atau akuntan publik mempunyai peranan dalam perkembangan bisnis global (Deasy, 2002). Auditor merupakan seseorang yang melakukan tugas pemeriksaan secara objektif disertai dengan menyajikan pendapat tentang kewajaran laporan keuangan perusahaan klien. Perusahaan memerlukan jasa auditor di Kantor Akuntan Publik untuk mengaudit laporan keuangannya agar informasinya dapat dipercaya dan digunakan oleh pemakai.

Kantor Akuntan Publik adalah organisasi di bidang jasa (Devi, 2014). Jasa yang diberikan oleh Kantor Akuntan Publik yaitu audit operasional, audit kepatuhan dan audit laporan keuangan. Audit adalah proses sistematik yang bertujuan memperoleh serta mengevaluasi bukti yang terkumpul dari pernyataan dan asersi kejadian ekonomi kemudian mengkomunikasikan hasilnya ke pihak yang berkepentingan. Audit memiliki tujuan menentukan tingkat kewajaran laporan keuangan antara pernyataan atau asersi dengan kriteria yang telah ditetapkan. Setiap auditor dalam Kantor Akuntan Publik melaksanakan tugas pemeriksaan harus sesuai dengan Standar Profesional Akuntan Publik agar kinerja auditor dapat dinilai baik. Kinerja auditor adalah suatu tindakan atau pelaksanaan tugas pemeriksaan yang telah dilakukan auditor dalam kurun waktu tertentu. 
Salah satu faktor yang mempengaruhi kinerja auditor yaitu independensi auditor. Kurangnya independensi dan semakin banyaknya kasus manipulasi menyebabkan pemakai laporan keuangan menurun kepercayaannya sehingga auditor dipertanyakan sebagai pihak yang independen oleh pemakai laporan keuangan. Penelitian yang dilakukan Nenni (2014) membuktikan bahwa independensi auditor berpengaruh terhadap kinerja auditor. Hal ini sejalan dengan penelitian yang dilakukan oleh Listiya (2016) dan Ernawati (2017) yang menunjukkan dengan adanya independensi auditor akan berpotensi mempengaruhi kinerja auditor. Berbeda dengan hasil penelitian tersebut, tidak adanya pengaruh yang signifikan antara independensi auditor dengan kinerja auditor ditemukan oleh Sapariyah (2011), Devi (2014), dan Pamilih (2014).

Faktor lain yang mempengaruhi kinerja auditor yaitu komitmen organisasi. Untuk memperbaiki kinerja maka harus membangun komitmen organisasi terlebih dahulu. Irfan Ikhsan Lubis (2011) mengatakan komitmen organisasi adalah seberapa jauh seseorang berpihak kepada tujuan organisasinya dan mempunyai niat untuk menjaga keanggotaannya pada organisasi. Penelitian yang dilakukan oleh Yola (2015) membuktikan bahwa semakin tingginya komitmen organisasi maka kinerja akan meningkat. Hal ini sejalan pada penelitian yang dilakukan oleh Fernando et al (2005), Nenni (2014), Zahra (2014) dan Ananta (2015) yang menunjukkan dengan adanya komitmen organisasi akan berpotensi mempengaruhi kinerja auditor. Berbeda dengan penelitian tersebut, tidak adanya pengaruh antara komitmen organisasi dengan kinerja auditor ditemukan oleh Somers (1998) dan Saputro (2015). 
Made Cintia Arta Pratiwi dan Anak Agung Ngurah Bagus Dwirandra. Tekanan ...

Berdasarkan paparan penelitian pengaruh independensi auditor dan komitmen organisasi pada kinerja auditor ditemukan hasil yang variatif / tidak konsisten atau masih kontroversi yang diduga karena adanya faktor lain yang mempengaruhi hubungan antara variabel bebas dengan variabel terikat. Secara konseptual dan hasil riset empiris, terdapat beberapa variabel yang diduga berperan memoderasi pengaruh independensi dan komitmen organisasi pada kinerja auditor, salah satu di antaranya patut dipertimbangkan, yaitu tekanan waktu. Ahituv (1998) mengatakan tekanan waktu adalah tuntutan pada auditor untuk dapat mengefisienkan waktu yang telah disusun. Penelitian yang dilakukan oleh Sunar (2016) membuktikan bahwa dengan adanya tekanan waktu maka auditor akan bekerja dengan lebih efisien. Hal ini sejalan dengan penelitian yang dilakukan oleh Pakaya (2015) dan Azizah (2015) yang menunjukkan bahwa tekanan waktu berpengaruh positif terhadap kinerja auditor.

Berdasarkan uraian diatas maka pokok permasalahan dalam penelitian ini yaitu: 1) Apakah independensi auditor berpengaruh pada kinerja auditor?; 2) Apakah komitmen organisasi berpengaruh pada kinerja auditor?; 3) Apakah tekanan waktu berpengaruh pada kinerja auditor?; 4) Apakah tekanan waktu memoderasi pengaruh independensi auditor pada kinerja auditor?; 5) Apakah tekanan waktu memoderasi pengaruh komitmen organisasi pada kinerja auditor. Adapun tujuan yang ingin dicapai dalam penelitian ini yaitu: 1) Untuk memperoleh bukti empiris pengaruh independensi auditor pada kinerja auditor; 2) Untuk memperoleh bukti empiris pengaruh komitmen organisasi pada kinerja auditor; 3) Untuk memperoleh bukti empiris pengaruh tekanan waktu pada kinerja 
auditor; 4) Untuk memperoleh bukti empiris kemampuan tekanan waktu memoderasi pengaruh independensi auditor pada kinerja auditor; 5) Untuk memperoleh bukti empiris kemampuan tekanan waktu memoderasi pengaruh komitmen organisasi pada kinerja auditor.

Teori keagenan merupakan hubungan keagenan yang telah dijelaskan oleh Jensen dan Meckling (1976) adalah sebuah kontrak dimana pemilik perusahaan tidak mampu mengelola perusahaannya sendiri sehingga pemilik perusahaan mendelegasikan wewenangnya kepada pihak manajer untuk membuat keputusan yang terbaik bagi pemilik perusahaan. Auditor sebagai pihak ketiga yang independen dianggap mampu mengatasi konflik antara principal dan agent tersebut dengan tetap menjaga sikap independensinya serta memegang teguh komitmennya terhadap organisasi.

Fritz Heider mengatakan teori atribusi merupakan sikap individu dipengaruhi dari gabungan kekuatan internalnya serta eksternal. Atribusi internal dalam penelitian ini yaitu sikap independensi auditor dan komitmen auditor terhadap organisasinya sedangkan atribusi eksternal dalam penelitian ini yaitu tekanan waktu. Teori atribusi menyatakan atribusi eksternal dapat merubah perilaku seseorang. Oleh karena itu dengan adanya tekanan waktu sebagai atribusi eksternal dapat merubah sikap independen dan komitmen seorang auditor yang akan menyebabkan seorang auditor menciptakan perilaku fungsional atau disfungsional dalam melaksanakan tugasnya dan pada akhirnya akan berpengaruh pada kinerja auditor. Kerangka konseptual adalah hubungan logis antara kajian empirisnya serta landasan teorinya. Kerangka konseptual menunjukkan pengaruh 
antar variabel dalam penelitian. Kerangka konseptual penelitian yang digunakan dalam penelitian ini yaitu:

Tekanan Waktu Memoderasi Pengaruh Independensi Auditor dan Komitmen Organisasi pada Kinerja Auditor (Studi Empiris pada Kantor Akuntan Publik di Provinsi Bali)

\section{Kajian Teoritis:}

1. Teori Keagenan

2. Teori Atribusi

3. Kinerja Auditor

4. Independensi Auditor

5. Komitmen Organisasi

6. Tekanan Waktu

\section{Kajian Empiris:}

1. Nenni (2014)

2. Listiya (2016)

3. Ernawati (2017)

4. Yola (2015)

5. Zahra (2014)

6. Ananta (2015)

7. Sunar (2016)

8. Pakaya (2015)

9. Azizah (2015)

10. Halim (2014)

Variabel Penelitian :

Kinerja Auditor (Y), Independensi auditor $\left(\mathrm{X}_{1}\right)$, Komitmen organisasi $\left(\mathrm{X}_{2}\right)$, Tekanan Waktu (M)

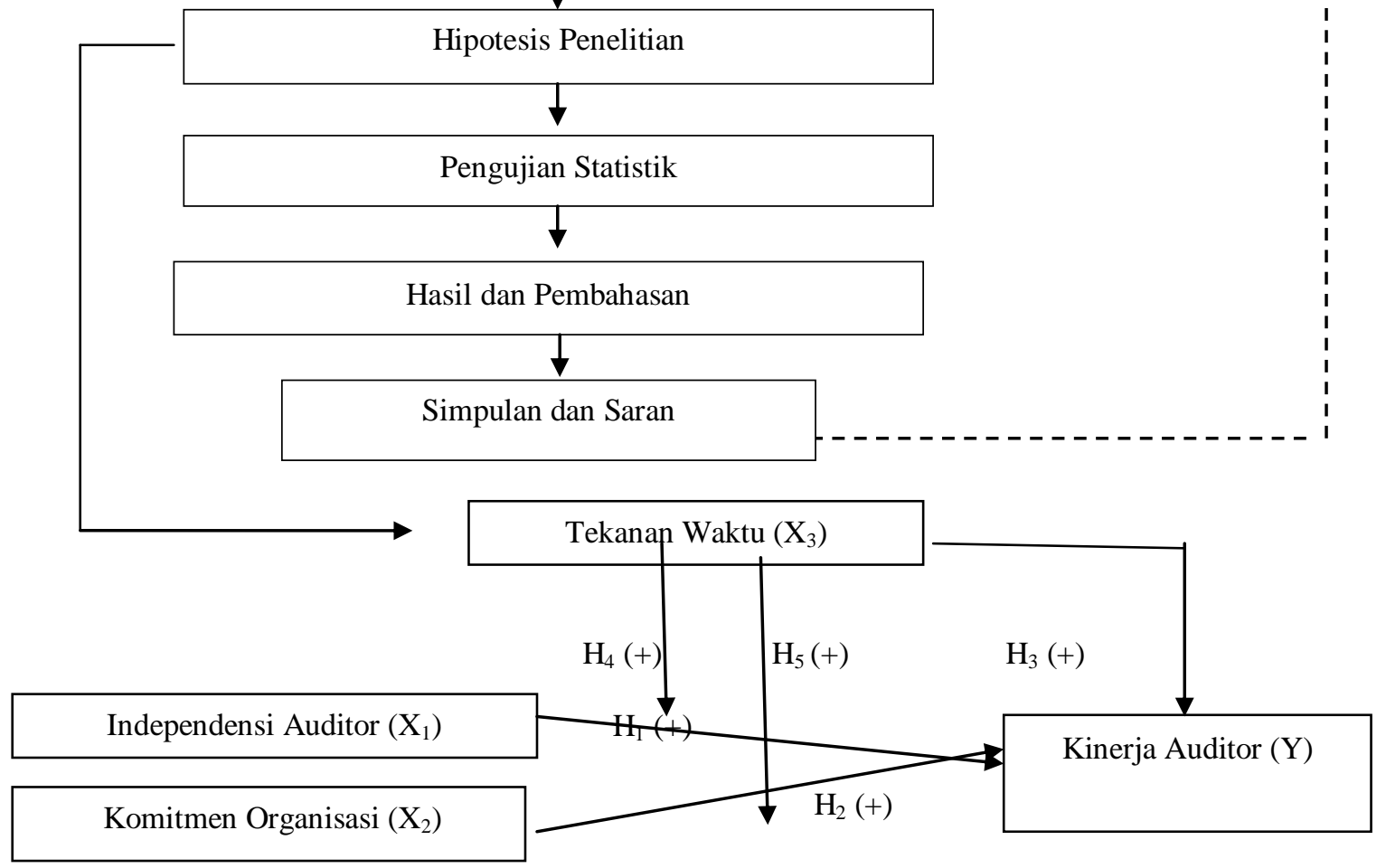

Gambar 1. Kerangka Konseptual Penelitian

Sumber : Data diolah, 2017 
Independensi adalah sikap mental yang dimiliki oleh auditor untuk tidak memihak dalam melaksanakan audit. Independensi auditor berpengaruh terhadap kinerja auditor. Semakin tinggi sikap independensi yang dimiliki auditor maka kinerja auditor yang dihasilkan akan semakin tinggi. Hasil penelitian yang dilakukan oleh Nenni (2014) membuktikan bahwa adanya pengaruh independensi auditor dan kinerja auditor dimana auditor memiliki independensi tinggi akan sulit untuk dipengaruhi serta sulit dikendalikan pihak luar ketika menilai faktanya dalam pemeriksaan dan ketika menyimpulkan serta memberikan opini sehingga akan lebih baik kinerjanya. Hal ini senada dengan penelitian yang dilakukan oleh Listiya (2016) dan Ernawati (2017). Berdasarkan kerangka pemikiran dan hasil riset tersebut, maka hipotesis pertama penelitian ini yaitu:

$\mathrm{H}_{1}$ : Independensi auditor berpengaruh positif pada kinerja auditor

Komitmen organisasi dapat dilihat dari tiga aspek yaitu identifikasi, keterlibatan dan loyalitas (Ferris dan Aranya, 1983 dalam Trisnaningsih, 2007). Identifikasi itu bagaimana auditor bekerja di tempat kerjanya dan saling mendukung dengan rekan kerja yang akan membuat auditor nyaman di tempat kerjanya. Keterlibatan itu bagaimana auditor terlibat terhadap organisasi untuk meningkatkan kinerja di dalam organisasinya. Loyalitas itu bagaimana menciptakan rasa memiliki terhadap organisasi setelah auditor terlibat dalam organisasi. Dengan adanya rasa memiliki maka kinerja auditor akan meningkat. Hasil penelitian yang dilakukan oleh Yola (2015) membuktikan bahwa semakin tinggi rasa komitmen organisasi dapat meningkatkan kinerja. Hal ini senada dengan penelitian yang dilakukan oleh Zahra (2014) dan Ananta (2015). 
Berdasarkan kerangka pemikiran dan hasil riset tersebut, maka hipotesis kedua penelitian ini yaitu:

$\mathrm{H}_{2}$ : Komitmen Organisasi berpengaruh positif pada kinerja auditor

Tekanan waktu adalah suatu keadaan yang menunjukkan auditor dituntut untuk melakukan efisiensi terhadap waktu yang telah disusun atau terdapat pembatasan waktu yang sangat ketat dan kaku (Nirmala dan Cahyonowati, 2013). Adanya anggaran waktu yang ketat merupakan hal yang lazim dan merupakan cara untuk mendorong auditor untuk bekerja lebih keras dan efisien. Hasil penelitian yang dilakukan oleh Sunar (2016) membuktikan bahwa semakin tinggi tekanan terhadap waktu yang diberikan dalam melaksanakan tugas pengauditan maka kinerja auditor akan semakin baik. Hal ini senada dengan penelitian yang dilakukan oleh Pakaya (2015) dan Azizah (2015). Berdasarkan kerangka pemikiran dan hasil riset tersebut, maka hipotesis ketiga penelitian ini yaitu:

$\mathrm{H}_{3}$ : Tekanan waktu berpengaruh positif pada kinerja auditor

Independensi auditor menjadi atribut penting dalam menjaga kualitas sebagai seorang auditor di mata masyarakat. Tepalagul dan Lin (2015) menyatakan bahwa menjaga kepercayaan masyarakat menjadi sesuatu yang penting dalam situasi apapun. Hasil penelitian yang dilakukan oleh Halim (2014) membuktikan bahwa independensi auditor dengan adanya tekanan waktu maka auditor akan bekerja dengan lebih efisien. Ini berarti bahwa seorang auditor yang sedang mengalami tekanan waktu maka akan termotivasi untuk melaksanakan tugasnya dengan efektif dan efisien. Untuk dapat menyelesaikan tugas dengan efektif dan efisien maka auditor akan mengurangi komunikasi dengan perusahaan 
klien. Komunikasi yang berkurang antara auditor dengan perusahaan klien menunjukkan bahwa terjaganya independensi auditor tersebut yang akan menyebabkan kinerja auditor meningkat. Berdasarkan kerangka pemikiran dan hasil riset tersebut, maka hipotesis keempat penelitian ini yaitu:

$\mathrm{H}_{4}$ : Tekanan waktu memperkuat pengaruh independensi auditor pada kinerja auditor

Auditor yang mempunyai komitmen terhadap organisasi yang tinggi akan tetap memegang teguh nilai dan tujuan organisasinya walaupun auditor dihadapi dengan tekanan waktu. Hasil penelitian yang dilakukan oleh Yola (2015) membuktikan semakin tinggi komitmen organisasi maka kinerja akan meningkat, selanjutnya tekanan waktu berpengaruh positif terhadap kinerja auditor ditemukan oleh Sunar (2016). Dengan tekanan waktu sebagai variabel moderasi akan menyebabkan komitmen organisasi berpengaruh positif terhadap kinerja auditor. Ini berarti bahwa seorang auditor yang sedang menghadapi tekanan waktu akan termotivasi untuk melaksanakan tugasnya sesuai dengan waktu yang telah disusun karena auditor ingin menunjukkan sikap loyalitas dan memegang teguh komitmennya dengan memiliki keyakinan yang kuat terhadap tujuan dan nilai organisasi serta bersedia untuk bekerja lebih keras demi mencapai tujuan organisasi yang akan mengakibatkan kinerja auditor meningkat. Berdasarkan kerangka pemikiran dan hasil riset tersebut maka hipotesis kelima penelitian ini yaitu:

$\mathrm{H}_{5}$ : Tekanan waktu memperkuat pengaruh komitmen organisasi pada kinerja auditor 


\section{METODE PENELITIAN}

Pada desain penelitian ini akan dijelaskan mengenai rencana menyeluruh dari penelitian yang mencakup seluruh hal yang akan dilakukan oleh peneliti mulai dari masalah penelitian dan membuat rumusan masalah, membangun hipotesis, melakukan pengolahan data dan analisis data yang kemudian dibahas dan diinterpretasikan sehingga peneliti dapat menarik kesimpulan dan memberikan saran untuk penelitian selanjutnya. Desain penelitian dapat dilihat di tabel sebagai berikut:

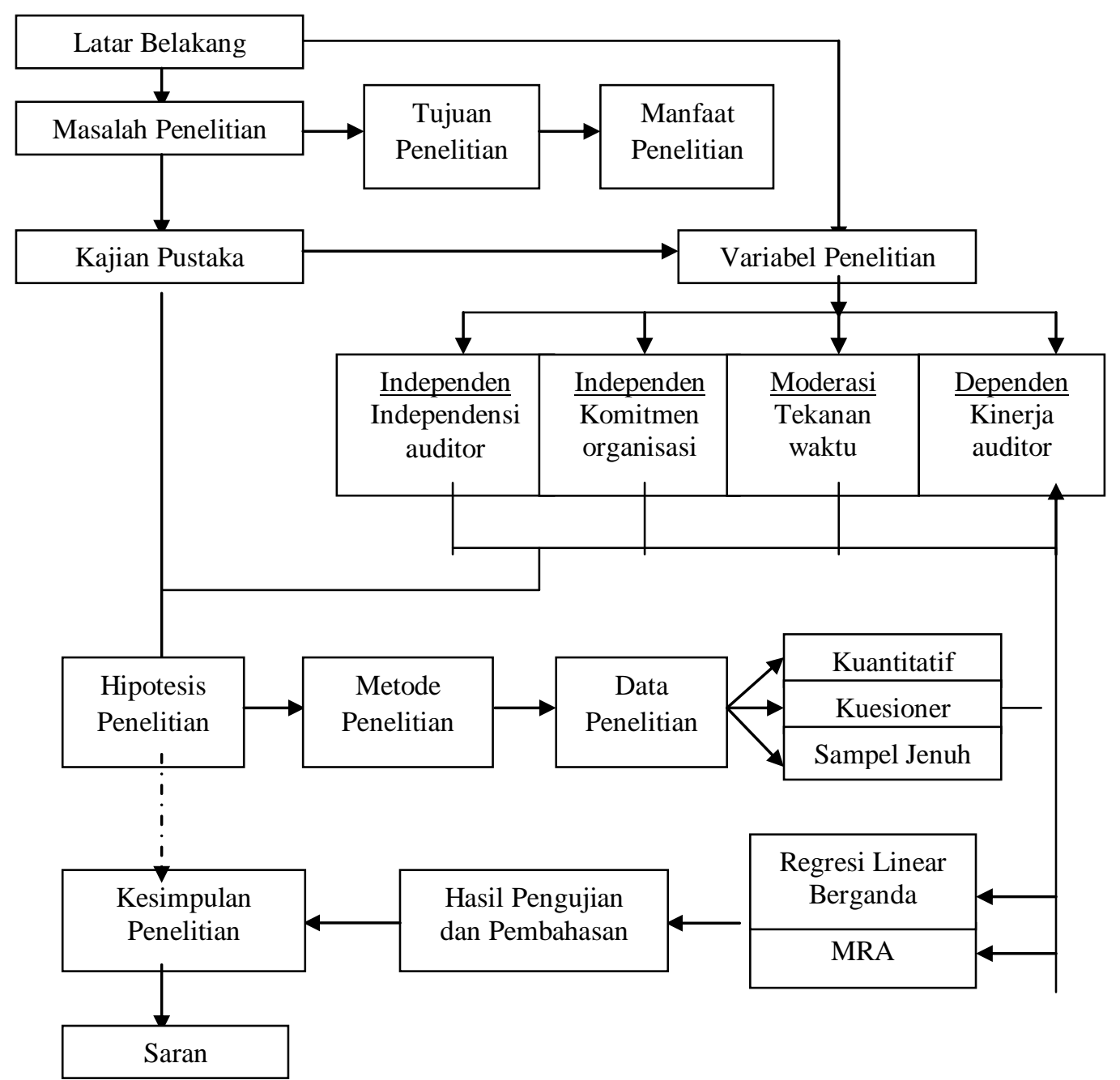

Sumber: Data diolah, 2017

Gambar 2. Desain Penelitian 

didapat lewat situs www.iapi.or.id. Kantor Akuntan Publik yang terdaftar bisa dilihat di tabel sebagai berikut:

\section{Tabel 1.}

Daftar Kantor Akuntan Publik di Provinsi Bali

\begin{tabular}{|c|c|c|}
\hline No & Nama KAP & Alamat KAP \\
\hline 1 & KAP Arnaya dan Darmayasa & $\begin{array}{l}\text { Jl. Gunung Catur IV Perum. Melang Hill No. 1, } \\
\text { Ubung, Denpasar } \\
\text { Telp: (0361) } 4714308\end{array}$ \\
\hline 2 & KAP Budhananda Munidewi & $\begin{array}{l}\text { Jl. Tukad Irawadi No. } 18 \text { A, Lantai } 2 \text { \& } 3 \\
\text { Kelurahan Panjer, Kecamatan Denpasar Selatan } \\
\text { Telp: (0361) } 245644\end{array}$ \\
\hline 3 & KAP. I Wayan Ramantha & $\begin{array}{l}\text { Jl. Batubulan, Tegaltamu, Dangin Puri Kauh } \\
\text { Denpasar, Bali. Telp: (0361) } 263643\end{array}$ \\
\hline 4 & KAP. Johan Malonda Mustika \& Rekan (Cab) & $\begin{array}{l}\text { Jl. Muding Indah I/5, Kerobokan, Kuta Utara, } \\
\text { Badung, Bali. Telp: (0361) } 434884\end{array}$ \\
\hline 5 & KAP. K. Gunarsa & $\begin{array}{l}\text { Jl. Tukad Banyusari Gg. II No.5 Telp: (0361) } \\
225580\end{array}$ \\
\hline 6 & KAP. Drs. Ketut Budiartha, Msi & $\begin{array}{l}\text { Jl. Gunung Agung Perum Padang Pesona, Graha } \\
\text { Adi A6, Denpasar, Bali. Telp: (0361) } 8849168\end{array}$ \\
\hline 7 & KAP. Drs. Sri Marmo Djogosarkono \& Rekan & $\begin{array}{l}\text { Jl. Gunung Muria Blok VE No.4, Monang } \\
\text { Maning, Denpasar, Bali. Telp: (0361) } 480033 \text {, } \\
\text { 480032, } 482422\end{array}$ \\
\hline 8 & KAP. Drs. Wayan Sunasdyana & $\begin{array}{l}\text { Jl. Pura Demak I Gang Buntu No. 89, Denpasar, } \\
\text { Bali. Telp: (0361) 7422329, } 8518989\end{array}$ \\
\hline 9 & KAP. Drs. Ketut Muliartha R.M. \& Rekan & $\begin{array}{l}\text { Jl. Drupadi No. 25, Denpasar, Bali. Telp: (0361) } \\
248110,265227\end{array}$ \\
\hline
\end{tabular}

Sumber: Data diolah, 2017

Obyek penelitian dalam penelitian ini yaitu independensi auditor, komitmen organisasi, tekanan waktu dan kinerja auditor pada Kantor Akuntan Publik di wilayah Provinsi Bali yang terdaftar pada Institut Akuntan Publik Indonesia pada tahun 2017.

Variabel dependen dalam penelitian ini yaitu kinerja auditor. Variabel independen dalam penelitian ini adalah independensi auditor dan komitmen 
organisasi. Variabel moderasi dalam penelitian ini adalah tekanan waktu. Ghozali (2016) mengklasifikasikan variabel moderasi menjadi 4 (empat) jenis yaitu pure moderasi (moderasi murni), quasi moderasi (moderasi semu), homologiser moderasi (moderasi potensial) dan Predictor moderasi (moderasi sebagai predictor).

Kinerja auditor merupakan sebagai hasil pekerjaan yang telah dilakukan auditor ketika menjalankan tugas berdasarkan kewajiban serta sebagai ukuran dalam menilai apakah pekerjaan telah dilaksanakan dengan baik atau sebaliknya. Kinerja auditor dinilai berdasarkan 7 pernyataan yang mengadopsi indikator yang dipergunakan oleh Ricky (2016) yaitu: a) kuantitas pekerjaan, b) kualitas pekerjaan, c) berpartisipasi dalam usulan konstruktif, d) meningkatkan prosedur audit, e) penilaian kinerja diri sendiri, f) penghargaan dari pihak lain, g) hubungan dengan klien.

Independensi auditor merupakan tindakan auditor tidak memihak serta tidak dipengaruhi dengan pihak luar. Independensi artinya akuntan publik sulit dipengaruhi dengan kepentingan pihak lainnya. Independensi auditor diukur dengan 6 pernyataan dengan mengadopsi indikator yang digunakan oleh Arifah (2012) yaitu: a) independensi penyusunan program, b) independensi investigatif, c) independensi pelaporan.

Komitmen organisasi adalah kekuatan relatif seseorang ketika mengidentifikasikan keikutsertaan diri di organisasinya. Komitmen organisasi diukur dengan 7 pernyataan dengan mengadopsi indikator yang digunakan oleh Setiyadi (2016) yaitu: a) rasa memiliki organisasi, b) loyalitas terhadap organisasi, 
c) mempunyai ikatan emosional dengan organisasi, d) banyak masalah jika keluar, e) mudah terikat dengan organisasi, f) konsekuensi negatif jika keluar perusahaan.

Tekanan waktu adalah masalah yang muncul dikarenakan terbatasnya waktu dan terbatasnya sumber daya yang diberikan ketika menjalankan suatu tugas. Tekanan waktu diukur dengan 7 pernyataan dengan mengadopsi indikator yang digunakan oleh Sita (2016) yaitu: a) ketepatan waktu, b) pencapaian anggaran waktu, c) tingkat efektivitas dan efisiensi kegiatan pengauditan, d) kinerja.

Populasi penelitiannya yaitu semua auditor yang bertugas di Kantor Akuntan Publik wilayah Provinsi Bali yang terdaftar di Institut Akuntan Publik Indonesia 2017 dengan total 76. Rincian auditor yang bertugas di KAP Bali dipaparkan dalam tabel yaitu:

Tabel 2.

Jumlah Auditor yang Bekerja pada Kantor Akuntan Publik di Provinsi Bali

\begin{tabular}{clc}
\hline No & \multicolumn{1}{c}{ Nama KAP } & Jumlah Auditor \\
\hline 1 & KAP Arnaya dan Darmayasa & 10 \\
2 & KAP Budhananda Munidewi & 6 \\
3 & KAP. I Wayan Ramantha & 10 \\
4 & KAP. Johan Malonda Mustika \& Rekan (Cab) & 10 \\
5 & KAP. K. Gunarsa & 3 \\
6 & KAP. Drs. Ketut Budiartha, Msi & 6 \\
7 & KAP. Drs. Sri Marmo Djogosarkono \& Rekan & 16 \\
8 & KAP. Drs. Wayan Sunasdyana & 5 \\
9 & KAP. Drs. Ketut Muliartha R.M. \& Rekan & 10 \\
\hline & TOTAL & 76
\end{tabular}

Sumber: Data diolah, 2017

Teknik pengambilan sampel dalam penelitian ini menggunakan metode non probability sampling dengan teknik sampling jenuh. Teknik sampling jenuh adalah teknik penentuan sampel bila menggunakan semua anggota populasi menjadi sampel. 
Made Cintia Arta Pratiwi dan Anak Agung Ngurah Bagus Dwirandra. Tekanan ...

Data yang digunakan dalam penelitian ini adalah data kuantitatif. Data kuantitatif ini diperoleh dari skor jawaban responden terhadap kuesioner yang mengacu pada pengukuran variabel yang digunakan. Sumber data dalam penelitian ini berasal dari data primer dan data sekunder. Data primer diperoleh secara langsung oleh peneliti dengan metode survey menggunakan kuesioner yang dibagikan dan diisi oleh auditor yang bekerja pada Kantor Akuntan Publik di Provinsi Bali yang terdiri dari instrumen dimana setiap instrumen terdapat pernyataan-pernyataan dengan menggunakan skala likert. Data sekunder seperti data daftar nama Kantor Akuntan Publik yang diakses melalui www.iapi.or.id.

Metode pengumpulan data dalam penelitian ini yaitu metode survey dengan menggunakan kuesioner yang dilakukan dengan cara memberi pertanyaan atau pernyataan secara tertulis kepada responden untuk dijawab (Sugiyono, 2014:199). Setiap variabel telah disiapkan pernyataan dengan jumlah yang berbeda antara satu dengan lainnya. Penelitian ini diukur menggunakan kuesioner dengan menggunakan skala likert 1-5.

Moderated Regression Analysis (MRA) merupakan aplikasi khusus regresi linier berganda dimana dalam persamaan regresinya mengandung unsur interaksi (perkalian dua atau lebih variabel independen). Adapun model rumus yang digunakan adalah sebagai berikut.

$Y=\alpha+\beta_{1} X_{1}+\beta_{2} X_{2}+\beta_{3} X_{3}+\varepsilon i$

$Y=\alpha+\beta_{1} X_{1}+\beta_{2} X_{2}+\beta_{3} X_{3}+\beta_{4} X_{1} X_{3}+\beta_{5} X_{2} X_{3}+\varepsilon i$

Keterangan:

Y : Kinerja Auditor

$\alpha \quad$ : Konstanta

$\beta_{1}-\beta_{5}$ : Koefisien regresi masing-masing faktor 
$\mathrm{X}_{1} \quad$ : Independensi Auditor

$\mathrm{X}_{2} \quad$ : Komitmen Organisasi

$\mathrm{X}_{3} \quad$ : Tekanan Waktu

$\mathrm{X}_{1} \cdot \mathrm{X}_{3}$ : interaksi Independensi Auditor dengan Tekanan Waktu

$\mathrm{X}_{2} . \mathrm{X}_{3}$ : interaksi Komitmen Organisasi dengan Tekanan Waktu

ei : Error term

\section{HASIL DAN PEMBAHASAN}

Hasil uji validitas dan reliabilitas pada penelitian ini dapat dilihat pada tabel yaitu:

Tabel 3.

Hasil Uji Validitas dan Reliabilitas

\begin{tabular}{|c|c|c|c|c|c|c|}
\hline No & Variabel & $\begin{array}{c}\text { Kode } \\
\text { Instrumen }\end{array}$ & $\begin{array}{c}\text { Nilai } \\
\text { Pearson } \\
\text { Correlation }\end{array}$ & Keterangan & $\begin{array}{c}\text { Cronbach's } \\
\text { alpha }\end{array}$ & Keterangan \\
\hline \multirow[t]{6}{*}{1} & \multirow{6}{*}{$\begin{array}{l}\text { Independensi } \\
\text { auditor }\left(\mathrm{X}_{1}\right)\end{array}$} & $\mathrm{X} 1.1$ & 0,605 & Valid & \multirow[t]{6}{*}{0,720} & \multirow[t]{6}{*}{ Reliabel } \\
\hline & & $\mathrm{X} 1.2$ & 0,681 & Valid & & \\
\hline & & $\mathrm{X} 1.3$ & 0,344 & Valid & & \\
\hline & & X1.4 & 0,430 & Valid & & \\
\hline & & $\mathrm{X} 1.5$ & 0,598 & Valid & & \\
\hline & & X1.6 & 0,671 & Valid & & \\
\hline \multirow[t]{7}{*}{2} & \multirow{7}{*}{$\begin{array}{c}\text { Komitmen } \\
\text { organisasi } \\
\left(\mathrm{X}_{2}\right)\end{array}$} & $\mathrm{X} 2.1$ & 0,544 & Valid & \multirow{7}{*}{0,791} & \multirow[t]{7}{*}{ Reliabel } \\
\hline & & $\mathrm{X} 2.2$ & 0,729 & Valid & & \\
\hline & & $\mathrm{X} 2.3$ & 0,929 & Valid & & \\
\hline & & X2.4 & 0,880 & Valid & & \\
\hline & & $X 2.5$ & 0,893 & Valid & & \\
\hline & & X2.6 & 0,847 & Valid & & \\
\hline & & $\mathrm{X} 2.7$ & 0,670 & Valid & & \\
\hline \multirow[t]{7}{*}{3} & \multirow{7}{*}{$\begin{array}{c}\text { Tekanan } \\
\text { waktu }\left(\mathrm{X}_{3}\right)\end{array}$} & X3.1 & 0,854 & Valid & \multirow[t]{7}{*}{0,792} & \multirow[t]{7}{*}{ Reliabel } \\
\hline & & X3.2 & 0,813 & Valid & & \\
\hline & & X3.3 & 0,855 & Valid & & \\
\hline & & X3.4 & 0,804 & Valid & & \\
\hline & & X3.5 & 0,749 & Valid & & \\
\hline & & X3.6 & 0,719 & Valid & & \\
\hline & & X3.7 & 0,782 & Valid & & \\
\hline \multirow[t]{7}{*}{4} & \multirow{7}{*}{$\begin{array}{c}\text { Kinerja } \\
\text { auditor (Y) }\end{array}$} & Y.1 & 0,849 & Valid & \multirow[t]{7}{*}{0,785} & \multirow[t]{7}{*}{ Reliabel } \\
\hline & & Y.2 & 0,734 & Valid & & \\
\hline & & Y.3 & 0,820 & Valid & & \\
\hline & & Y.4 & 0,864 & Valid & & \\
\hline & & Y.5 & 0,828 & Valid & & \\
\hline & & Y.6 & 0,705 & Valid & & \\
\hline & & Y.7 & 0,422 & Valid & & \\
\hline
\end{tabular}

Sumber: Data diolah, 2017

Berdasar tabel bisa dijelaskan instrumen penelitian yaitu jenis pernyataan independensi auditor $\left(\mathrm{X}_{1}\right)$, komitmen organisasi $\left(\mathrm{X}_{2}\right)$, tekanan waktu $\left(\mathrm{X}_{3}\right)$ serta kinerja auditor (Y) valid sebab hubungan antara nilai pernyataan dengan nilai 
totalnya lebih besar dari 0,30. Nilai cronbach's alpha untuk masing-masing variabel lebih besar dari 0,60. Jadi dapat dinyatakan bahwa semua variabel telah memenuhi syarat reliabilitas atau dapat dikatakan reliabel sehingga dapat digunakan dalam penelitian ini. Tabel memperlihatkan hasil analisis statistik deskriptif yaitu:

Tabel 4.

Hasil Analisis Statistik Deskriptif

\begin{tabular}{|c|c|c|c|c|c|}
\hline Variabel & $\begin{array}{l}\text { Jumlah } \\
\text { Sampel } \\
\end{array}$ & $\begin{array}{c}\text { Nilai } \\
\text { Minimum }\end{array}$ & $\begin{array}{c}\text { Nilai } \\
\text { Maksimum }\end{array}$ & Mean & $\begin{array}{l}\text { Standar } \\
\text { Deviasi }\end{array}$ \\
\hline $\begin{array}{l}\text { Independensi } \\
\text { Auditor }\end{array}$ & 50 & 3,17 & 4,83 & 4,077 & 0,368 \\
\hline $\begin{array}{l}\text { Komitmen } \\
\text { Organisasi }\end{array}$ & 50 & 2,29 & 5,00 & 3,611 & 0,661 \\
\hline $\begin{array}{l}\text { Tekanan } \\
\text { Waktu }\end{array}$ & 50 & 2,00 & 4,86 & 3,583 & 0,754 \\
\hline $\begin{array}{l}\text { Kinerja } \\
\text { Auditor }\end{array}$ & 50 & 2,57 & 5,00 & 3,666 & 0,620 \\
\hline
\end{tabular}

Sumber: Data diolah, 2017

Berdasarkan Tabel dapat disimpulkan bahwa jumlah pengamatan (N) penelitian ini berjumlah 50 dan secara keseluruhan nilai rata-rata dari masingmasing variabel diatas 3 dan mendekati skala likert 5. Bila dibandingkan antara masing-masing variabel maka variabel independensi auditor memiliki nilai ratarata yang tertinggi sedangkan nilai rata-rata yang terendah yaitu variabel tekanan waktu. Variabel independensi auditor memiliki nilai minimum sebesar 3,17 dan nilai maksimum sebesar 4,83 dengan nilai rata - rata sebesar 4,077 dan standar deviasi sebesar 0,368. Variabel komitmen organisasi memiliki nilai minimum sebesar 2,29 dan nilai maksimum sebesar 5,0 dengan nilai rata - rata sebesar 3,611 dan standar deviasi sebesar 0,661. Tekanan waktu mempunyai nilai terendah 2,00 serta nilai tertinggi 4,86, nilai mean 3,583 dan standart deviation sebesar 0,758. Kinerja auditor memiliki nilai minimum sebesar 2,57 dan nilai 
maksimum sebesar 5,0 dengan nilai rata - rata sebesar 3,666 dan standar deviasi sebesar 0,620. Hasil pengujian Kolmogorov-Smirnov, uji multikolinearitas dan uji glejser bisa diperlihatkan di tabel yaitu:

Tabel 5.

Hasil Uji Asumsi Klasik

\begin{tabular}{lcccc}
\hline \multicolumn{1}{c}{ Variabel } & $\begin{array}{c}\text { Normalitas } \\
\text { Sig. 2 Tailed }\end{array}$ & \multicolumn{2}{c}{ Multikolinearitas } & Heteroskedastisitas \\
Tolerance & VIF & Signifikansi \\
\hline $\begin{array}{l}\text { Independensi } \\
\begin{array}{l}\text { Auditor } \\
\text { Komitmen }\end{array}\end{array}$ & 0,799 & 1,251 & 0,531 \\
$\begin{array}{l}\text { Organisasi } \\
\text { Tekanan Waktu }\end{array}$ & 0,532 & 0,999 & 1,001 & 0,697 \\
\hline \multicolumn{2}{c}{ Sumber: Data diolah, 2017} & 0,800 & 1,250 & 0,848 \\
\hline
\end{tabular}

Hasil uji Kolmogorov-Smirnov di tabel membuktikan nilai signifikansinya lebih besar daripada 0,05. Hal ini memperlihatkan persamaan regresi dalam model ini mempunyai data normal. Masing-masing variabel bebas tersebut memiliki nilai tolerance lebih besar dari 0,10 dan memiliki nilai VIF lebih kecil dari 10 . Kemudian kesimpulannya independensi auditor, komitmen organisasi serta tekanan waktu tidak ada gejala multikolinearitas. Tabel hasil pengujian glejser di atas menunjukkan bahwa seluruh variabel memiliki nilai signifikansi di atas 0,05 sehingga model regresi ini tidak mengandung adanya gejala heteroskedastisitas.

Tabel 6.

Hasil Uji Regresi Linear Berganda

\begin{tabular}{|c|c|c|c|c|c|}
\hline \multirow[t]{2}{*}{ Variabel } & \multicolumn{2}{|c|}{$\begin{array}{l}\text { Unstandardized } \\
\text { Coefficient }\end{array}$} & \multirow{2}{*}{$\begin{array}{c}\begin{array}{c}\text { Standardized } \\
\text { Coefficient }\end{array} \\
\text { Beta }\end{array}$} & \multirow[t]{2}{*}{ Sig } & \multirow{2}{*}{$\begin{array}{l}\text { Hasil Uji } \\
\text { Hipotesis }\end{array}$} \\
\hline & B & Std. Error & & & \\
\hline Constant & 12,470 & 5,696 & & 0,034 & \\
\hline $\mathrm{X}_{1}$ & $-0,384$ & 0,231 & $-0,195$ & 0,103 & $\mathrm{H}_{1}$ Ditolak \\
\hline$X_{2}$ & 0,564 & 0,098 & 0,601 & 0,000 & $\mathrm{H}_{2}$ Diterima \\
\hline $\mathrm{X} 3$ & 0,332 & 0,096 & 0,404 & 0,001 & $\mathrm{H}_{3}$ Diterima \\
\hline Adjusted $\mathrm{R}_{\text {square }}$ & $:$ & 0,461 & & & \\
\hline Sig. F Fitung & $:$ & 0,000 & & & \\
\hline
\end{tabular}

Dari tabel di atas dapat disusun persamaan regresi linear berganda yaitu:

$Y=\alpha+\beta_{1} X_{1}+\beta_{2} X_{2}+\beta_{3} X_{3}+\varepsilon i$ 
Made Cintia Arta Pratiwi dan Anak Agung Ngurah Bagus Dwirandra. Tekanan ...

$\mathrm{Y}=12,470-0,384 \mathrm{X}_{1}+0,564 \mathrm{X}_{2}+0,332 \mathrm{X}_{3}+\mathrm{e}$

Interpretasi dari persamaan di atas adalah jika nilai konstanta $(\alpha)$ menunjukkan nilai positif maka mempunyai artian bila independensi auditor, komitmen organisasi serta tekanan waktu konstan di angka 0, jadi kinerja auditor tetap ada 12,470 satuan. Nilai koefisien $\left(\beta_{1}\right)-0,384$. $\beta_{1}$ negatif memperlihatkan jika independensi auditor satu satuan meningkat, jadi kinerja auditor menurun 0,384 satuan. Nilai koefisien $\left(\beta_{2}\right) 0,564$. $\beta_{2}$ positif membuktikan jika komitmen organisasi satu satuan meningkat, jadi kinerja auditor meningkat 0,564 satuan. Nilai koefisien $\left(\beta_{3}\right)$ 0,332. $\beta_{3}$ positif memperlihatkan jika tekanan waktu satu satuan meningkat, jadi kinerja auditor meningkat 0,332 satuan.

Tabel 7.

Hasil Moderated Regression Analysis (MRA)

\begin{tabular}{|c|c|c|c|c|c|}
\hline \multirow[t]{2}{*}{ Variabel } & \multicolumn{2}{|c|}{$\begin{array}{l}\text { Unstandardized } \\
\text { Coefficient }\end{array}$} & \multirow{2}{*}{$\begin{array}{c}\begin{array}{c}\text { Standardized } \\
\text { Coefficient }\end{array} \\
\text { Beta } \\
\end{array}$} & \multirow[t]{2}{*}{ Sig } & \multirow{2}{*}{$\begin{array}{l}\text { Hasil Uji } \\
\text { Hipotesis }\end{array}$} \\
\hline & $\mathbf{B}$ & Std. Error & & & \\
\hline Constant & $-33,667$ & $-38,047$ & & 0,381 & \\
\hline $\mathrm{X}_{1}$ & 1,966 & 1,540 & 0,999 & 0,208 & \\
\hline $\mathrm{X}_{2}$ & 0,145 & 0,529 & 0,154 & 0,786 & \\
\hline X3 & 2,021 & 1,389 & 2,456 & 0,153 & \\
\hline $\mathrm{X}_{1} \mathrm{X}_{3}$ & $-0,087$ & 0,056 & $-3,283$ & 0,129 & H4 Ditolak \\
\hline $\mathrm{X}_{2} \mathrm{X}_{3}$ & 0,017 & 0,020 & 0,693 & 0,411 & H5 Ditolak \\
\hline Adjusted $\mathrm{R}_{\text {square }}$ & $:$ & 0,471 & & & \\
\hline Sig. $F_{\text {hitung }}$ & $:$ & 0,000 & & & \\
\hline
\end{tabular}

Persamaan regresi yang diperoleh berdasarkan model regresi moderasi pada penelitian yaitu:

$Y=\alpha+\beta_{1} X_{1}+\beta_{2} . X_{2}+\beta_{3} X_{3}+\beta_{4} X_{1} X_{3}+\beta_{5} X_{2} X_{3}+\varepsilon i$

$Y=-33,667+1,966 X_{1}+0,145 X_{2}+2,021 X_{3}-0,087 X_{1} X_{3}+0,017 X_{2} X_{3}+e$

Interpretasi dari persamaan diatas adalah jika nilai konstanta $(\alpha)$ menunjukkan nilai negatif maka mempunyai artian bila independensi auditor, komitmen organisasi serta tekanan waktu konstan di angka 0, jadi kinerja auditor 33,667. Nilai koefisien $\left(\beta_{1}\right)$ 1,966 maka memperlihatkan jika independensi auditor 
satu satuan meningkat, jadi kinerja auditor meningkat 1,966 tetapi anggapan variabel bebas lainnya dianggap konstan. Nilai koefisien $\left(\beta_{2}\right)$ 0,145 maka membuktikan jika komitmen organisasi satu satuan meningkat, jadi kinerja auditor meningkat 0,145 tetapi anggapan variabel bebas lainnya dianggap konstan. Nilai koefisien $\left(\beta_{3}\right)$ 2,021 maka memperlihatkan jika tekanan waktu meningkat satu satuan, maka kinerja auditor akan meningkat sebesar 2,021 dengan asumsi variabel bebas lainnya dianggap konstan.

Nilai koefisien $\left(\beta_{4}\right)$ interaksi antara independensi auditor dengan tekanan waktu -0,087 maka membuktikan setiap interaksi independensi auditor dan tekanan waktu satu satuan meningkat jadi tidak mampu mempengaruhi kinerja auditor. Nilai koefisien $\left(\beta_{5}\right)$ interaksi antara komitmen organisasi dengan tekanan waktu adalah sebesar 0,017. Hal ini menunjukkan bahwa setiap interaksi komitmen organisasi dengan tekanan waktu meningkat satu satuan maka tidak mampu mempengaruhi kinerja auditor.

Hipotesis pertama $\left(\mathrm{H}_{1}\right)$ tentang independensi auditor mempunyai hubungan dengan kinerja auditor yaitu semakin tingginya independensi auditor maka kinerja akan meningkat. Melalui analisis regresi linear berganda diperoleh temuan berbeda dimana independensi auditor berpengaruh negatif terhadap kinerja auditor maka semakin tingginya independensi auditor akan semakin rendah kinerja auditor. Hal ini selaras pada penelitian yang dilakukan oleh Sapariyah (2011), tidak adanya pengaruh yang signifikan antara independensi auditor dengan kinerja auditor. Independensi tidak berpengaruh pada kinerja 
auditor dikarenakan independensi auditor tidak bisa menerangkan dengan kuat keragaman kinerja auditor.

Hipotesis kedua $\left(\mathrm{H}_{2}\right)$ mengenai komitmen organisasi mempunyai hubungan dengan kinerja auditor yaitu semakin tingginya komitmen organisasi maka kinerja akan meningkat. Melalui analisis regresi linear berganda diperoleh hasil yang mendukung hipotesis semakin tingginya komitmen organisasi seorang auditor jadi semakin tingginya kinerja auditor. Dengan demikian selaras pada penelitian yang dilaksanakan Yola (2015), bahwa komitmen organisasi berpengaruh positif pada kinerja auditor. Komitmen Organisasi pada organisasi sangat dibutuhkan dikarenakan menumbuhkan komitmen mengikutsertakan semua yang bertugas didalamnya dan melibatkan psikis seseorang serta memberikan rasa organisasinya itu segalanya.

Hipotesis ketiga $\left(\mathrm{H}_{3}\right)$ tentang tekanan waktu mempunyai hubungan dengan kinerja auditor yaitu semakin tingginya tekanan waktu maka kinerja akan meningkat. Melalui analisis regresi linear berganda diperoleh hasil yang mendukung hipotesis bahwa semakin tinggi tekanan waktu yang dirasakan seorang auditor jadi semakin tingginya kinerja auditor. Dengan demikian selaras pada penelitian yang dilaksanakan Sunar (2016) membuktikan bahwa semakin tinggi tekanan terhadap waktu yang diberikan dalam melaksanakan tugas pengauditan maka kinerja auditor akan semakin baik. Tekanan waktu yang diberikan pada pelaksanan tugas pengauditan harus disikapi dengan positif oleh auditor, karena tekanan waktu merupakan kendali dari audit untuk 
mengidentifikasi lingkup masalah yang mampu merangsang staf auditor untuk mendapatkan kinerja yang efisien.

Hipotesis keempat ditolak, yaitu tekanan waktu tidak mampu memoderasi hubungan independensi auditor pada kinerja auditor. Meningkatnya tekanan waktu yang dirasakan seorang auditor dalam menjaga independensinya maka tidak mampu mempengaruhi kinerja auditor didalam organisasi tersebut. Untuk mengetahui jenis moderasi dalam penelitian ini maka tingkat signifikansi $X_{1}$ dan $X_{3}$ lebih besar dari 0,05 maka $\beta_{1}$ dan $\beta_{3}$ non signifikan. Oleh karena $\beta_{1}$ dan $\beta_{3}$ non signifikan maka jenis moderasi dalam hipotesis ini yaitu moderasi potensial (homologizer moderator) yang artinya bahwa variabel moderasi tidak berinteraksi dengan variabel independen dan tidak berhubungan secara signifikan baik dengan variabel dependen atau independen maka variabel tersebut potensial menjadi variabel moderasi.

Hipotesis kelima ditolak, yaitu tekanan waktu tidak mampu memoderasi pengaruh komitmen organisasi terhadap kinerja auditor. Tekanan waktu meningkat yang dirasakan seorang auditor ketika berkomitmen organisasi jadi tidak mampu mempengaruhi kinerja auditor pada organisasi tersebut. Untuk mengetahui jenis moderasi dalam hipotesis ini maka tingkat signifikansi $\mathrm{X}_{2}$ dan $\mathrm{X}_{3}$ lebih besar dari 0,05 maka $\beta_{2}$ dan $\beta_{3}$ non signifikan. Oleh karena $\beta_{2}$ dan $\beta_{3}$ non signifikan maka jenis moderasi dalam hipotesis ini yaitu moderasi potensial (homologizer moderator) yang artinya bahwa variabel moderasi tidak berinteraksi dengan variabel independen dan tidak berhubungan secara signifikan baik dengan 
Made Cintia Arta Pratiwi dan Anak Agung Ngurah Bagus Dwirandra. Tekanan ...

variabel dependen atau independen maka variabel tersebut potensial menjadi variabel moderasi.

Hal ini tidak mendukung teori atribusi dalam penelitian ini yaitu tekanan waktu sebagai atribusi eksternal tidak dapat merubah atribusi internal seperti independensi auditor dan komitmen organisasi. Ini berarti bahwa dengan ada atau tidaknya tekanan waktu yang dirasakan auditor maka seorang auditor tetap memegang teguh sikap independensi dan rasa komitmen terhadap organisasinya sehingga akan tetap menghasilkan kinerja auditor yang baik. Auditor sebagai pihak ketiga yang independen dan memiliki rasa komitmen terhadap organisasi maka dapat mengatasi konflik antara principal dan agen sehingga hal ini mendukung teori keagenan yang digunakan dalam penelitian ini.

Hasil penelitian ini dapat digunakan sebagai masukan bagi auditor untuk selalu meningkatkan sikap independensi secara obyektif yang kemungkinan akan terdapat permasalahan kesulitan dalam memperoleh bukti yang signifikan, maka dari itu diharapkan dapat diatasi melalui cara auditor dalam melakukan audit dengan luwes, santun dan melihat situasi klien serta mempertahankan rasa komitmen terhadap organisasinya. Kantor Akuntan Publik juga perlu memberikan tambahan pengetahuan secara teknikal mengenai strategi pengauditan dalam menghadapi tekanan-tekanan yang dirasakan auditor seperti tekanan waktu sehingga auditor dapat menyelesaikan tugasnya dengan efisien dan efektif sesuai waktu yang telah direncanakan dan kinerja auditor akan menjadi lebih baik. 


\section{SIMPULAN}

Berdasarkan pembahasan hasil penelitian yang telah diuraikan maka dapat disimpulkan yaitu independensi auditor berpengaruh negatif pada kinerja auditor. Ini berarti bahwa semakin tinggi independensi auditor maka kinerja auditor akan semakin rendah. Komitmen Organisasi berpengaruh positif pada kinerja auditor. Ini berarti bahwa semakin tinggi komitmen organisasi maka kinerja auditor akan semakin baik. Tekanan waktu berpengaruh positif pada kinerja auditor. Ini berarti bahwa semakin tinggi tekanan waktu maka kinerja auditor akan semakin baik. Tekanan waktu tidak bisa memoderasi hubungan independensi auditor terhadap kinerja auditor. Dengan adanya tekanan waktu maka pengaruh independensi auditor terhadap kinerja auditor tidak berubah. Tekanan waktu tidak bisa memoderasi hubungan komitmen organisasi terhadap kinerja auditor. Dengan adanya tekanan waktu maka pengaruh komitmen organisasi terhadap kinerja auditor tidak berubah.

Berdasarkan pembahasan hasil penelitian dan simpulan yang telah diuraikan maka saran yang akan diberikan yaitu pernyataan kuesioner yang diberikan kepada responden menunjukkan kecenderungan auditor tidak bebas dalam melakukan pelaporan fakta-fakta karena masih adanya pengaruh dari pihak luar seperti perusahaan klien sehingga untuk kedepannya diharapkan untuk lebih meningkatkan independensi terhadap pelaporan fakta-fakta agar kinerja auditor semakin baik. Penelitian berikutnya bisa menambah variabel keinginan berpindah (turn over intention), karena adanya kemungkinan kurang loyalnya auditor pada organisasi, kurangnya rasa memiliki dan kurangnya memegang teguh profesi 
Made Cintia Arta Pratiwi dan Anak Agung Ngurah Bagus Dwirandra. Tekanan ...

sebagai auditor. Penelitian selanjutnya juga dapat menambahkan variabel supervisi audit karena manajemen Kantor Akuntan Publik sebaiknya lebih meningkatkan mengenai supervisi audit dan memberikan pendidikan pelatihan secara berkala kepada auditor maka ketika keadaan apapun auditor serta keahlian yang dimiliki bisa menuntaskan tugasnya secara baik serta tepat waktu.

\section{REFERENSI}

Ahituv, Niv dan Igbaria, Magid. 1998. The Effect of Time Pressure and Completeness of Information on Decision Making. Journal Management Information Systems. P: 153172.

Ananta. 2015. Interitas Sebagai Pemoderasi Pengaruh Komitmen Organisasi Pada Kinerja Auditor. E-Jurnal Akuntansi Universitas Udayana 10.3 (2015): 841- 851

Arens dan Loebbecke. 2003. Auditing Pendekatan Terpadu. Edisi Indonesia. Penerbit Salemba Empat, Jakarta.

Arifah, Nurul. 2012. Pengaruh Independensi Auditor, Komitmen Organisasi Dan Gaya Kepemimpinan Terhadap Kinerja Auditor. Skripsi. Fakultas Ekonomi Dan Bisnis Universitas Hasanuddin Makassar.

Azizah, Nurul. 2015. "Pengaruh Ketidakjelasan Peran, Konflik Peran, Profesionalisme, Budaya Organisasi, dan Tekanan Anggaran Waktu (Time Budget Pressure) terhadap Kinerja Auditor". Skripsi. Jurusan Akuntansi. Fakultas Ekonomi. Universitas Negeri Semarang.

Boon, O. K., Safa, M. S., Arumugam, V. (2006). TQM Practice and Affective Commitment:A Case of Malaysian Semiconductor Packaging Organizations. International Journal of Management Entrepreunership. Vol. 2. No. 1. Page. 37-55. Munich personal RePEc Archive.

Coram, P., Ng, J., \& Woodliff, D. 2003. A Survey of Time Budget Pressure and Reduced Audit Quality Among Australia Auditors. Australia Accounting Review, 13(1), 38-44.

Deasy Ariyanti Rahayuningsih. 2002. Harapan dan Kenyataan dalam Berkarir di Kantor Akuntan Publik: Suatu Perbandingan antara Mahasiswa Akuntansi dan Auditor. Jurnal Bisnis dan Akuntansi, 4(3): h:229-252.

Devi. 2014. Pengaruh Independensi Auditor dan Gaya Kepemimpinan Terhadap Kinerja Auditor Dengan Komitmen Organisasi Sebagai Variabel 
Intervening. Jurnal Ilmiah Ekonomi dan Bisnis Vol. 11, No. 2, September 2014: $339-351$

Ernawati. 2017. Pengaruh Independensi, Etika Profesi, Profesionalisme, Dan Komitmen Organisasi Terhadap Kinerja Auditor. Skripsi. Fakultas Ekonomi dan Bisnis Islam Institut Agama Islam Negeri Surakarta

Fernando, J., Mulki, J.P., and Marshall, G.W . (2005). A-meta-analysis of the realationship between organizational commitment and salesperson job performance. Journal of business research (58), 705-714.

Ferris, K. dan Aranya, N.1983. A Comparison of two organizational commitment scales. Personnel Psychology, 36, 87-98.

Gasperz, Jefri. 2014. "Pengaruh Tekanan Anggaran Waktu Sebagai Variabel Moderasi terhadap Hubungan antara Faktor Individu dan Kualitas Audit”. Jurnal Dinamika Akuntansi, Keuangan dan Perbankan, Vol. 3 : 33-45. Universitas Pattimura.

Govindarajan, Vijay. 1986. Impact of Participation in the Budgetary Process on Managerial Attitude and Performance, Universalistic and Contengency Perspective. Decisions Sciences. pp: 496-516.

Halim, A. et al. 2014. "Effect of Competence and Auditor Independence on Audit Quality with Audit Time Budget and Professional Commitment as a Moderation Variable". International Journal of Business and Management Invention, Vol. 3 : 64-74.

Ikhsan, A. (2011). Akuntansi perilaku. Jakarta: Salemba Empat.

Institut Akuntan Publik Indonesia. 2016. www.iapi.or.id.

Jensen MC and JH Meckling. 1976. Theory of Firm : Managerial Behavior, Agency Cost and Ownership Structure. Journal of Financial Economics, 3, pp: 305-360.

Jusup, Al Haryono. 2014. Auditing Edisi II. Yogyakarta: Sekolah Tinggi Ilmu Ekonomi.

Kalbers, Lawrence P., dan Fogarty, Timothy J. 1995. Professionalism Its Consequences: A Study of Internal Auditors. Auditing: A Journal of Practice. Vol. 14. No. 1: 64-86.

Kelley, T. dan Seiler, R. E. (1982), Auditor Stress and Time Budgets, The CPA Journal, December, pp. 24-34. 
Listiya. 2016. Pengaruh Independensi, Gaya Kepemimpinan Dan Budaya Organisasi Terhadap Kinerja Auditor. Skripsi. Fakultas Ekonomi Universitas Negeri Yogyakarta.

Luthans, Fred. (2011). Organizational Behavior : An Evidence-Based Approach. New York: McGraw-Hill.

Meyer, J.P., Allen, N.J., Smith, C.a., 1993.Commitment is Cosly : New Approaches Establish The Missing Link Between and Performance, Human Relation, Vol.50, No.6: 701-726

Mindarti, Ceacilia Sri. 2015. Pengaruh Karakteristik Individu Terhadap Kinerja Auditor. ISSN 1979 - 6471. Volume XVIII No. 3, Desember 2015. Jurnal Ekonomi dan Bisnis.

Mulyadi. 2008. Sistem Akuntansi. Cetakan Keempat. Jakarta : Salemba Empat.

Murray, D. 1990. The Performance Effect of Participative Budgeting an Interpretation of Intervening and Moderating Variables, Behavioral Reseach in Accounting, 2, pp: 104-123.

Nenni. 2014. Pengaruh Independensi Auditor, Gaya Kepemimpinan, Komitmen Organisasi dan Budaya Organisasi terhadap Kinerja Auditor (Studi Empiris Pada Kantor Akuntan Publik di Surakarta dan Yogyakarta). Skripsi. Fakultas Ekonomi dan Bisnis Universitas Muhammadiyah Surakarta.

Nirmala dan Cahyonowati. 2013. Pengaruh Independensi, Pengalaman, Due Professional Care, Akuntabilitas, Kompleksitas Audit, Dan Time Budget Pressure Terhadap Kualitas Audit. Diponegoro Journal Of Accounting, Vol. 2, No. 3.Semarang.

Nor, Mohd Nazli Mohd, et all. 2010. Auditors' Perception of Time Budget Pressure and Reduced Audit Quality Practices: A Preliminary Study From Malaysian Context. Edith Cowan University.

Pakaya, Mohammad Reynaldhy dkk. 2015. Pengaruh Tekanan Anggaran Waktu (Time Budget Pressure) Terhadap Kualitas Audit pada Inspektorat Kota Gorontalo. Skripsi Fakultas Ekonomi dan Bisnis Universitas Negeri Gorontalo.

Pamilih, ismail, (2014), Pengaruh Indepedensi, Gaya Kepemimpinan, Komitmen Organisasi dan pemahaman Good Governance tehadap Kinerja Auditor Pemerintah (studi pada kantor BPKP perwakilan Yogyakarta). 
Ricky. 2016. Pengaruh Beban Kerja, Kepuasan Kerja, Self Efficacy dan Time Budget Pressure pada Kinerja Auditor Kantor Akuntan Publik di Provinsi Bali. Skripsi. Fakultas Ekonomi dan Bisnis Universitas Udayana.

Sapariyah, Rina Ani. 2011. Pengaruh Good Governance dan Independensi Auditor Terhadap Kinerja Auditor dan Komitmen Organisasi (Survey pada Kantor Akuntan Publik di Surakata). Jurnal Ekonomi Bisnis dan Perbankan, Mei, Vol 19, No. 16

Saputro. 2015. Pengaruh Independensi, Gaya Kepemimpinan, Komitmen Organisasi dan Pemahaman Good Governance Terhadap Kinerja Auditor Pemerintah (Studi Empiris Pada BPKP Perwakilan Jawa Tengah. Jurnal Manajemen dan Bisnis Volume 19, Nomor 1, Juni 2015, hlm 64-79

Setiyadi. 2016. Pengaruh Gaya Kepemimpinan, Komitmen Organisasi dan Pemahaman Sistem Informasi Akuntansi pada Kinerja Auditor Kantor Akuntan Publik di Bali. Skripsi. Fakultas Ekonomi dan Bisnis Universitas Udayana

Sita. 2016. Pengaruh Tekanan Waktu Terhadap Kinerja Auditor : Whistleblowing Intention Sebagai Variabel Pemoderasi (Studi Empiris Pada Kantor Akuntan Publik di Provinsi Bali. E-Jurnal Akuntansi Universitas Udayana Vol.19.2. Mei (2017): 1088-1115

Somers and Birnbaum. 1998. Work-Related Commitment and Job Performance: It's Also The Nature of The Performance That Counts. Journal of Organizational Behavior, (19) : 621-634.

Sososutikno, Cristina. 2003. Hubungan Tekanan Anggaran Waktu dengan Perilaku Disfungsional serta Pengaruhnya terhadap Kualitas Audit. Simposium Nasional Akuntansi VI.

Sugiyono. 2014. Metode Penelitian Bisnis. Cetakan Ketujuh Belas. Bandung: CV Alfabeta.

Sunar. 2016. Pengaruh Pendidikan, Fee, Komitmen dan Tekanan Waktu Pada Kinerja Auditor Kantor Akuntan Publik. E-Jurnal Akuntansi Universitas Udayana Vol.15.1. April (2016): 1-16

Tepalagul, Nopmanee \& Lin, Ling. 2015. "Auditor Independence and Audit Quality: A Literature Review”. Journal of Accounting, Auditting and Finance, Vol. 30 (1) : 101- 121.

Trisnaningsih, Sri. 2007. Independensi Auditor dan Komitmen Organisasi sebagai Mediasi Pengaruh Pemahaman Good Governance, Gaya Kepemimpinan dan Budaya Organisasi Terhadap Kinerja Auditor. Simposium Akuntansi Nasional X Makasar 26-28 Juli 2007. 
Made Cintia Arta Pratiwi dan Anak Agung Ngurah Bagus Dwirandra. Tekanan ...

Yola. 2015. Pengaruh Komitmen Organisasi, Profesionalisme dan Perilaku Etis Terhadap Kinerja Auditor di Kantor Akuntan Publik Wilayah Yogyakarta. Skripsi. Fakultas Ekonomi Universitas Negeri Yogyakarta.

Zahra. 2014. Investigating the Effect of Organization Commitment on Performance of Auditors in the Community of Certified Accountants. interdisciplinary journal of contemporary research in business february 2014 vol 5, no 10 